\title{
Engineering Geological Evaluation of Kakoragad Small Hydroelectric Project, Uttarakashi District, Uttarakhand
}

\author{
Bagri, D.S $S^{\mathrm{a}}$, Anbalagan, $\mathrm{R}^{\mathrm{b}}$ and Neethu, $\mathrm{S}^{\mathrm{c}}$ \\ ${ }^{a}$ Department of Geology, HNB Garhwal University, Tehri Campus, Uttarakhand \\ ${ }^{b}$ Professor, Department of Earth Sciences, Indian Institute of Technology, Roorkee \\ ${ }^{c}$ Research Scholar, Department of Earth Sciences, Indian Institute of Technology, Roorkee
}

\begin{abstract}
The proposed Kakoragad small hydroelectric project is a run of the river scheme, on Kakora River near Harsil in Uttarkashi district of Uttarakhand. The water will be diverted by an $18 \mathrm{~m}$ long rectangular trench type weir at an altitude of $\pm 2942 \mathrm{~m}$. The diverted water will be carried to the powerhouse through power tunnels over a distance of $1629 \mathrm{~m}$ to produce $12.5 \mathrm{MW}$ of electricity. The whole project is located within the rocks of Vaikrita Group. This study includes detailed discussions on geological setting in addition to highlighting the anticipated Engineering Geological problems likely to be encountered during construction of the project. The rocks at the project site have been classified using Rock Mass Rating (RMR) system and also by $Q$-system in order to predict rock load and support requirements.
\end{abstract}

Keywords: Kakoragad small hydroelectric project, $R M R, Q$-system, in-situ stresses, remedial measures

\section{Introduction}

The snow fed perennial rivers of Himalaya have huge hydropower potential. This non-exhaustible resource is an effective means to meet the rapidly rising energy requirements of the country. Several mega and micro scale hydroelectric projects are already functioning in the Himalayan region, while many more are under construction as well as planning stages across the Himalayan Rivers. The suitable location for Run-of-the-River Schemes (RORS), in Himalaya is a challenging task due to the fragility and high seismicity of the terrain. Since the terrain is highly sensitive environmentally, safe water conductor structures such as tunnels are more preferred as compared to open channels, which involve huge cuttings of the slope and other attendant environmental issues. These structures have minimum environmental problems, easy to construct and maintain with extremely high stability against earthquakes. The stability of underground openings is dependent on rock mass condition, in-situ stresses, support stiffness, size and shape of the cavity, method of construction and sequence of construction practice among other factors. In the present case, the Engineering Geological problems associated with the construction of a small hydropower project has been discussed. Here, the proposed rectangular trench type weir will help to ensure free flow of water without stagnating the water across the river course.

The Kakoragad small hydroelectric project is a Run-of-the river scheme (RORS) for power generation by exploiting the hydro power potential of the Kakora stream, a tributary of the Bhagirathi River. The project is situated near Harsil, about $75 \mathrm{~km}$ from Uttarkashi towards Gangotri (Fig 1). The Kakora stream is a perennial stream, which originates from the snow clad mountains having a peak elevation of $5900 \mathrm{~m}$ and flows in the south-west direction up to Harsil village, where it meets the Bhagirathi River. This Engineering Geological problems of this small hydroelectric project have been discussed with particular reference to five important project components namely diversion weir, water conductor system, forebay, penstock and powerhouse.

\section{Geological Setting Of Project Area}

The Kakoragad small hydroelectric project is situated in Higher Himalayan terrain of Garhwal Himalaya. The rocks exposed in and around the project site belongs to Vaikrita Group. The region has undergone high grade metamorphism resulting in the formation of Garnet-Quartz-Mica Granulite interbedded with Biotite-Mica Schist. The Biotite-Mica Schist shows trapped emplacements of anhedral to subhedral crystals of quartz. Thick debris cover could be seen all along the stretch of the Kakora stream from Harsil and further upstream up to the proposed weir site. However, a small patch of rock is seen at the proposed weir site. Debris materials mainly consisting of big rock blocks mixed with silty soil are present close to the valley face on the left bank near diversion site and desilting tank. At the diversion site, rocks show well developed foliations with less developed joints. Huge thickness of debris found at 


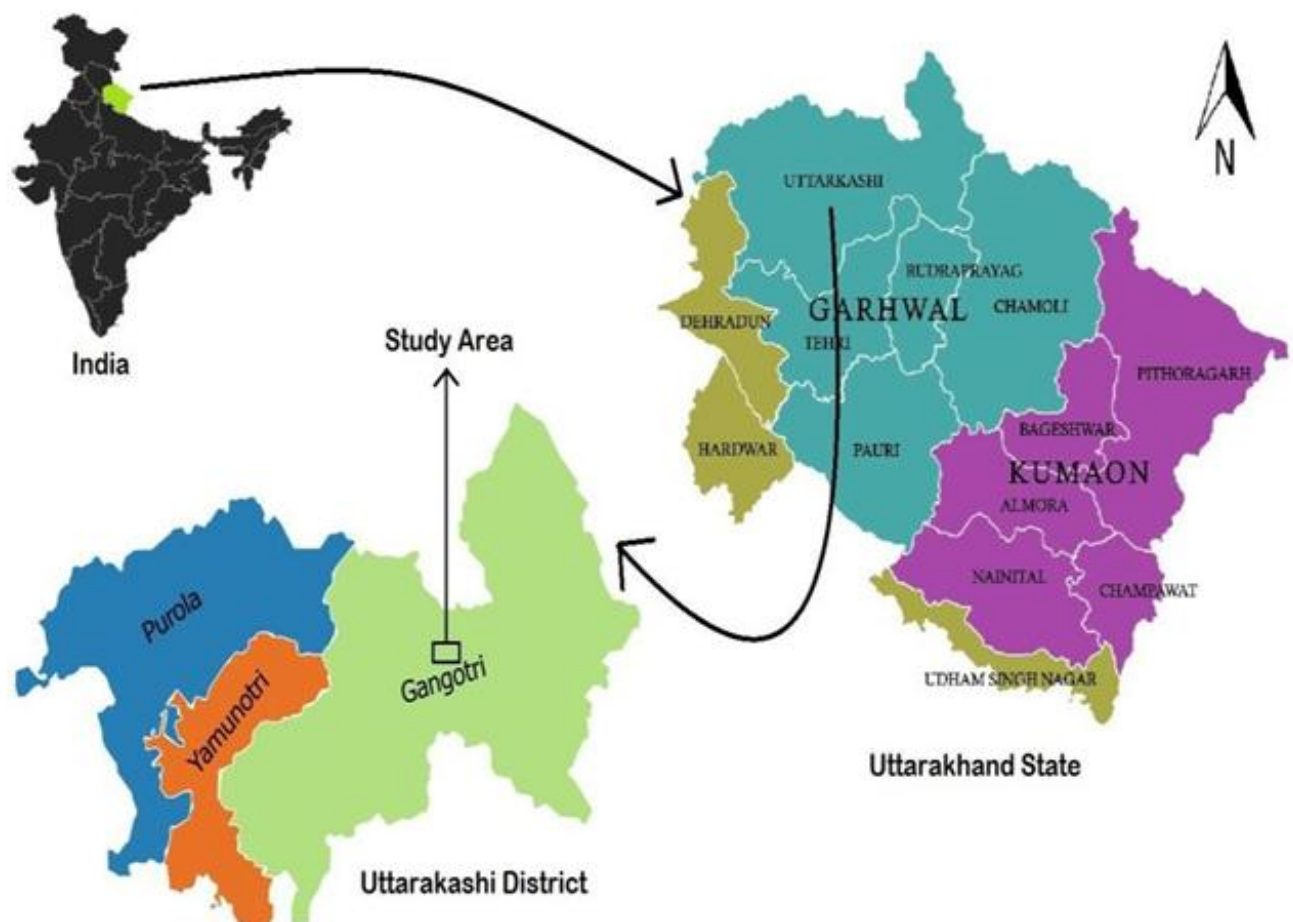

Fig.1. Location Map of study area

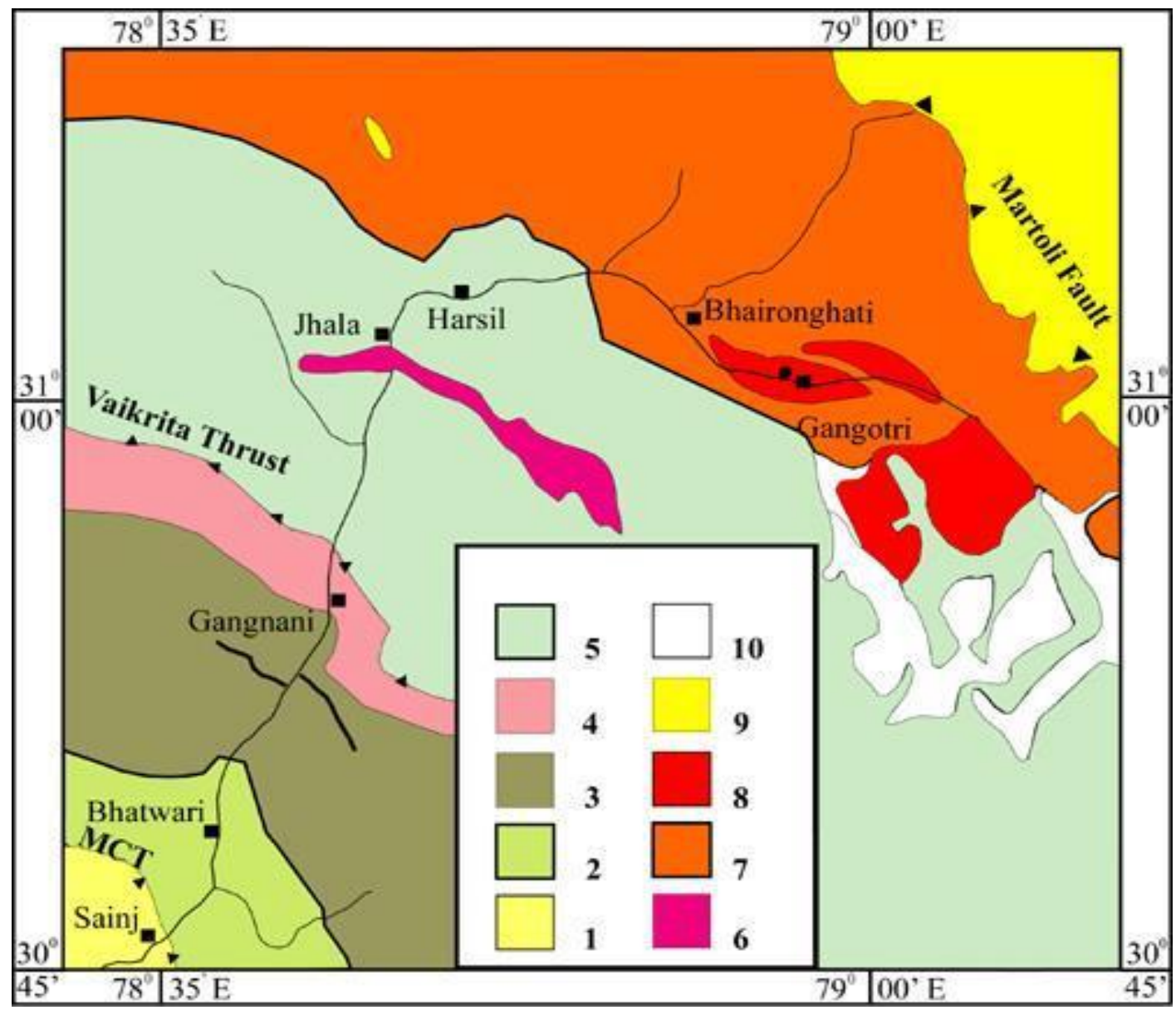

Fig 2. Geology around project site 
1. Lesser Himalaya (LH) Proterozoic sequence: Higher Himalayan Crystallines (HHC)

2. Bhatwari Group-Porphyroblastic granite gneiss, garnetiferous mica schist, amphibolites

3. Mylonitized augen gneiss, mica schist, amphibolite

4. Phyllonite, schist

5. Sillimanite, kyanite, staurolite, garnetiferous schist, gneiss, migmatite

6. Augen gneiss

7. Bhaironghati granite

8. Gangotri leucogranite

9. Tethyan sedimentary zone

10. Glaciers, debris etc

diversion site surrounding the rock exposure contain minerals such as quartz, mica and other clay minerals. The in situ rocks exposures seen in diversion tunnel, forebay and powerhouse sites mainly consist of massive, hard and well jointed micaceous quartzites. Brown colored debris having silty clay matrix mixed with rock blocks of varying size are present along the proposed penstock site. The Geology around the project site is shown in Fig. 2 .

\subsection{Diversion weir}

\section{Engineering Geological Problems Of Project Components}

Though the Kakora valley in general is tight and V-shaped in nature, the valley gets fairly widened to a width of about $20 \mathrm{~m}$ to $25 \mathrm{~m}$ at the proposed diversion weir site of the project $(\mathrm{El} \pm 2942 \mathrm{~m})$. A small patch of insitu rock present at the site is moderately weathered in nature. Fairly fresh to fresh rocks are likely to be available at depth. These are good rocks for tying the diversion weir on the left bank. Fairly fresh to fresh rocks are seen exposed on the right bank. The trench weir can be tied to the rocks seen on the banks

\subsection{Desilting tank}

The desilting tank is proposed to be located about 30m downstream of the weir site on the left bank at $\mathrm{El} \pm 2940 \mathrm{~m}$. The debris materials consisting of assorted rock blocks and alluvial boulders mixed with silty sand matrix are present at the site. In order to accommodate the tank, it may involve cutting of hill slope. Moreover, since the passage leading to the tank and tank itself will be located just adjoining the water course, suitable protection wall has to be designed around the construction area to protect it from floods.

\subsection{Power tunnel}

In view of the rugged rocky mountains and thick vegetation cover of trees and bushes in the entire area, it is planned to construct a ' $\mathrm{D}$ ' shaped power tunnel of $2 \mathrm{~m}$ (width) $\times 2.5 \mathrm{~m}$ (height) size to serve as the water conductor system with free water flow inside the tunnel. The inlet will be located at an elevation of $\pm 2490 \mathrm{~m}$ within debris materials. The power tunnel will be traversing through debris materials initially for a distance of about $100 \mathrm{~m}$ and will pass through rocks afterwards. In the initial reaches, the tunnel may collapse during excavation due to loose nature of the debris materials. It is essential to provide continuous support in this reach until rock exposures are met with. The presence of groundwater inside the debris may also cause more unstable conditions on the roof of tunnel. Hence, the excavation should progress with utmost care so that over break conditions can be prevented.

\subsection{Forebay}

The forebay is planned to be located close to the top of the Kakora ridge at a height of EL $\pm 2490 \mathrm{~m}$. The slopes are steep at the planned forebay site with inclinations of about $45^{\circ}$ towards $\mathrm{N} 160^{\circ}$. Since the foliation dip into the hill and one of the two joints is askew to slope direction, they do not pose problems of slope stability. The other joint, though dipping in the same direction as that of slope it dips an angle $\left(75^{\circ}\right)$ more than that of slopes $\left(45^{\circ}\right)$. Hence this also will not create any problem of instability to the slope. Overall, it may be mentioned that the intersection due to joints and foliations within the rocks do not form unstable rock wedges and as such the slopes in general are stable in nature.

\subsection{Penstock}

The penstock alignment, located in the Bhagirathi valley runs mostly on the debris materials resulted due to past landslides. The penstock with a diameter of $1.25 \mathrm{~m}$ is located between elevations of $2939 \mathrm{~m}$ and $2536 \mathrm{~m}$. The debris materials consist of brown colored silty clay matrix mixed with rock blocks of varying size ranging from 5 to $30 \mathrm{~cm}$, which constitute about $20 \%$ of the total materials. The debris materials are well 
compacted, stable and the bed rock may not be available at shallow depth, the thickness of the debris is likely to increase at lower levels close to power house. Hence, the anchor blocks may be designed taking into consideration of the debris present on the slopes.

\subsection{Powerhouse}

The powerhouse is located on the right bank of the Bhagirathi River at an elevation of $2536 \mathrm{~m}$ on a small terrace close to the Bhagirathi River. The general slope above the powerhouse is about of $55^{\circ}$ towards $\mathrm{N}$ $230^{\circ}$. At this site, the foliation which is the dominant geological discontinuity, dips into the hill and hence overall the slope is stable. However, the cut slopes and control measures have to be designed properly.

\section{Rock Mass Classification Of Project Site}

The rocks exposed in different units of the project site have been classified using rock mass rating (RMR) system (Bieniawski, 1979) and Q-system (Barton et al., 1974). The shear strength parameters cohesion (c) and angle of friction $\left(\Phi^{\circ}\right)$ are assessed by RMR system. Q-system has used to derive rock pressures and support requirements. The ratings of RMR and Q-system are shown in Table 1 and Table 2 respectively.

Table 1. RMR values of rocks at different components

\begin{tabular}{|c|c|c|c|c|c|}
\hline $\begin{array}{l}\text { Parameters/ Properties } \\
\text { of Rock Mass }\end{array}$ & Diversion & Inlet & $\begin{array}{c}\text { Above tunnel } \\
\mathrm{H}=3400 \mathrm{~m}\end{array}$ & Forebay & Power House \\
\hline Point Load Index(MPa) & 9.4 & 4.7 & 14.9 & 9.7 & 8 \\
\hline RQD & 20 & 17 & 20 & 20 & 20 \\
\hline $\begin{array}{l}\text { Spacing of } \\
\text { Discontinuity }\end{array}$ & 15 & 10 & 15 & 10 & 10 \\
\hline $\begin{array}{l}\text { Condition of } \\
\text { Discontinuity }\end{array}$ & 30 & 30 & 30 & 25 & 30 \\
\hline $\begin{array}{l}\text { Ground Water } \\
\text { Condition }\end{array}$ & 10 & 15 & 15 & 15 & 15 \\
\hline RMR value & 87 & 84 & 95 & 82 & 87 \\
\hline Class No & I & I & I & I & I \\
\hline Average stand up time & $\begin{array}{c}20 \mathrm{yr} \text { for } 15 \mathrm{~m} \\
\text { span }\end{array}$ & $\begin{array}{c}20 \mathrm{yr} \text { for } \\
15 \mathrm{~m} \text { span }\end{array}$ & $\begin{array}{c}20 \mathrm{yr} \text { for } 15 \mathrm{~m} \\
\text { span }\end{array}$ & $\begin{array}{c}20 \mathrm{yr} \text { for } \\
15 \mathrm{~m} \text { span }\end{array}$ & $\begin{array}{c}20 y r \text { for } 15 \mathrm{~m} \\
\text { span span }\end{array}$ \\
\hline $\begin{array}{c}\text { Cohesion(c) of Rock } \\
\text { Mass(MPa) }\end{array}$ & $>0.4$ & $>0.4$ & $>0.4$ & $>0.4$ & $>0.4$ \\
\hline
\end{tabular}

Table 2. Description, rating of parameters \& Q-values of different components

\begin{tabular}{|c|c|c|c|c|c|}
\hline Parameters & Diversion & Inlet & Above tunnel & Fore bay & Power House \\
\hline RQD & 98.5 & 85.3 & 95.2 & 95.2 & 91.9 \\
\hline $\mathrm{Jn}$ & 6 & 6 & 9 & 12 & 6 \\
\hline $\mathrm{Jr}$ & 3 & 3 & 4 & 3 & 4 \\
\hline $\mathrm{Ja}$ & 1 & 2 & 1 & 2 & 0.75 \\
\hline $\mathrm{JW}$ & 1 & 1 & 1 & 1 & 1 \\
\hline $\mathrm{SRF}$ & 1 & 1 & 1 & 1 & 15.3 \\
\hline $\mathrm{RQD} / \mathrm{Jn}$ & 16.4 & 14.2 & 10.5 & 7.9 & \\
\hline
\end{tabular}


Engineering Geological Evaluation of Kakoragad Small Hydroelectric Project, Uttarakashi ..

\begin{tabular}{|c|c|c|c|c|c|} 
& & & & & \\
\hline Jr/Ja & 3 & 1.5 & 4 & 1.5 & 5.3 \\
\hline Jw/ SRF & 1 & 1 & 1 & 1 & 1 \\
\hline Q-Value & 49.2 & 21.3 & 42 & 11.85 & 81.1 \\
\hline $\begin{array}{c}\text { Frictional } \\
\text { angle }\left(\Phi^{\circ} \text { of }\right. \\
\text { Rock Mass }\end{array}$ & $45^{\circ}$ & $45^{\circ}$ & $45^{\circ}$ & $45^{\circ}$ & $45^{\circ}$ \\
\hline
\end{tabular}

Where $\mathrm{Jn}=$ Joint set number, $\mathrm{Jr}=$ Joint roughness number, $\mathrm{Ja}=$ Joint alteration number, $\mathrm{JW}=$ Joint water parameter, $\mathrm{SFR}=$ Stress reduction factor, $\mathrm{RQD}=$ Rock Quality Designation

\section{Estimation Of Support Pressure}

\subsection{Support pressure estimation using RMR}

Support pressure can be calculated from the formula;

$\mathrm{P}=[(100-\mathrm{RMR}) / 100] \times \times_{\gamma} \mathrm{B}$

$\mathrm{P}=$ Support Load

$\mathrm{B}=$ Tunnel Width in $\mathrm{m}$

$\gamma=$ Density of rock in $\mathrm{Kg} / \mathrm{m}^{3}$

It is seen than very low support is required for the rock type with high RMR and relatively high support pressure is required for rocks of low RMR. Support pressure estimation for different units of the project is given using RMR system (Table 3).

Table 3. Support pressure estimation from RMR

\begin{tabular}{|c|c|c|c|c|c|}
\hline Parameters & Diversion & Inlet & Above tunnel & Fore bay & Power house \\
\hline RMR & 87 & 84 & 95 & 82 & 87 \\
\hline Tunnel width $(\mathrm{m})$ & 2.5 & 2.5 & 2.5 & 2.5 & 2.5 \\
\hline $\begin{array}{c}\text { Density of the } \\
\text { rock }\left(\mathrm{Kg} / \mathrm{m}^{3}\right)\end{array}$ & 2760 & 3680 & 2654.55 & 2700 & 3111.1 \\
\hline $\begin{array}{c}\text { support } \\
\text { pressure }\left(\mathrm{Kg} / \mathrm{m}^{2}\right)\end{array}$ & 897 & 1472 & 331.80 & 1215 & 1011.10 \\
\hline $\begin{array}{l}\text { Support } \\
\text { pressure(MPa) }\end{array}$ & 0.00879 & 0.014 & 0.00325 & 0.0119 & 0.0099 \\
\hline
\end{tabular}

\subsection{Ultimate Support Pressure}

Barton et al $(1974,1975)$ plotted support capacities of 200 underground openings against the rock mass quality (Q). They found following empirical correlation for ultimate support pressure:

$$
\begin{aligned}
& P_{v}=\left(0.2 / J_{r}\right) Q^{-1 / 3} \\
& P_{h}=\left(0.2 / J_{r}\right) Q_{w}{ }^{-1 / 3}
\end{aligned}
$$

Where,

$\mathrm{Pv}=$ Ultimate roof support pressure in $\mathrm{MPa}, \mathrm{Ph}=$ Ultimate wall support pressure in $\mathrm{MPa}, \mathrm{Q}=$ Rock mass quality

$\mathrm{Qw}=$ Wall rock mass quality

Here, the Jr value plays very important role in stability of underground openings. Consequently, support capacities may be independent of opening size as believed by Terzaghi (1946)

The wall factor $\mathrm{Qw}$ is determined by multiplying $\mathrm{Q}$ by a factor which depends on the magnitude of $\mathrm{Q}$ as given below. 


\begin{tabular}{|c|c|}
\hline $\begin{array}{c}\text { Range } \\
\text { of Q }\end{array}$ & $\begin{array}{c}\text { Wall } \\
\text { Factor Qw }\end{array}$ \\
\hline$>10$ & $5.0 \mathrm{Q}$ \\
\hline $0.1-1$ & $2.5 \mathrm{Q}$ \\
\hline$<0.1$ & $1.0 \mathrm{Q}$ \\
\hline
\end{tabular}

Barton et al further suggested that if number of joints less than three, the ultimate roof pressure and ultimate wall pressure can be calculated as follows:

$$
\begin{aligned}
& P= \frac{\left\lceil 0.2\left(J_{n}\right)^{1 / 2} \times Q^{-1 / 3}\right\rceil}{{ }^{3\left(J_{n}\right)}} \\
& \underset{h}{P}=\frac{\left\lceil 0.2\left(J_{n}\right)^{1 / 2} \times Q_{w}^{-1 / 3}\right\rceil}{{ }^{3\left(J_{n}\right)}}
\end{aligned}
$$

Table 4. Shown the ultimate support pressure estimated for rocks at different components

\begin{tabular}{|l|l|l|l|l|l|}
\hline Parameters & Diversion & Inlet & Above tunnel & Fore bay & Power house \\
\hline $\mathrm{Q}$ & 49.2 & 21.3 & 42 & 11.85 & 81.1 \\
\hline $\mathrm{Pv}(\mathrm{Mpa})$ & 0.0149 & 0.019 & 0.0144 & 0.029 & 0.01 \\
\hline $\begin{array}{l}\text { Support } \\
\text { category }\end{array}$ & 9 & 13 & 9 & 13 & 9 \\
\hline $\begin{array}{l}\text { Type of } \\
\text { support factor }\end{array}$ & $\begin{array}{l}\mathrm{B}(\mathrm{utg}) \\
2.5-3 \mathrm{~m}\end{array}$ & $\mathrm{Sb}(\mathrm{utg})$ & $\begin{array}{l}\mathrm{B}(\mathrm{utg}) \\
2.5-3 \mathrm{~m}\end{array}$ & $\begin{array}{l}\mathrm{B}(\mathrm{utg}) \\
1.5-2 \mathrm{~m}\end{array}$ & $\begin{array}{l}\mathrm{B}(\mathrm{utg}) \\
2.5-3 \mathrm{~m}\end{array}$ \\
\hline $\begin{array}{l}\text { Wall } \\
(\mathrm{Qw}=5 \mathrm{Q})\end{array}$ & 106.5 & 210.0 & 59.25 & 405.5 \\
\hline $\mathrm{Ph}(\mathrm{MPa})$ & 0.0087 & 0.0115 & 0.0084 & 0.0197 & 0.0055 \\
\hline $\begin{array}{l}\text { Support } \\
\text { category }\end{array}$ & 9 & 13 & 9 & 13 & 9 \\
\hline $\begin{array}{l}\text { Type } \\
\text { support }\end{array}$ & $\mathrm{B}(\mathrm{utg})$ & $\mathrm{Sb}(\mathrm{utg})$ & $\mathrm{B}(\mathrm{utg})$ & $\mathrm{B}(\mathrm{utg})$ & $1.5-2 \mathrm{~m}$ \\
\hline
\end{tabular}

$\mathrm{Sb}=$ Spot bolting, B systematic Bolting; (utg) = untensioned, grouted.

\subsection{Estimation of maximum unsupported span}

The maximum unsupported span for different rock types under different conditions calculated from the following formula;

Maximum unsupported span $=2 \times E S R \times Q^{0.4}$

Here, Excavation Support Ratio $($ ESR $)=1.6$

Table 5. Maximum unsupported span for rocks at different locations

\begin{tabular}{|c|c|c|c|c|c|}
\hline Parameters & Diversion & Inlet & $\begin{array}{c}\text { Above } \\
\text { tunnel }\end{array}$ & Fore bay & Power house \\
\hline $\mathrm{Q}$ & 49.2 & 21.3 & 42 & 11.8 & 81.1 \\
\hline ESR & 1.6 & 1.6 & 1.6 & 1.6 & 1.6 \\
\hline $\begin{array}{c}\text { Maximum } \\
\text { Unsupported } \\
\text { Span }\end{array}$ & 15.2 & 10.876 & 14.27 & 8.617 & 18.567 \\
\hline
\end{tabular}

\subsection{Calculation of Bolt and Anchor Length}

The Bolt (L) and Anchor Length (La) calculated by using following equation;

$\mathrm{L}=(2+0.15 \mathrm{~B}) / \mathrm{ESR}$

$\mathrm{La}=0.4 \mathrm{~B} / \mathrm{ESR}$ 
Where, B is span of tunnel i.e. $2.5 \mathrm{~m}$

So, here

Length of Bolt $(\mathrm{L})=[2+(0.15 \times 2.5)] / 1.6=1.48 \mathrm{~m}$

Anchor length $(\mathrm{La})=(0.4 \times 2.5) / 1.6$

$=\quad 0.625 \mathrm{~m}$

\subsection{Calculation of Bolt spacing/ Anchor spacing}

Bolt spacing calculated by using following formula;

$\mathrm{A}=1 / \sqrt{\mathrm{P}}$

Where, $\mathrm{a}=$ Bolt spacing

$\mathrm{P}=$ Support pressure capacity in $\mathrm{kg} / \mathrm{cm}^{2}$

Table 6. Bolt Spacing for rocks at different locations

\begin{tabular}{|c|c|c|c|c|}
\hline Parameters & Inlet & Above tunnel & Fore bay & Power house \\
\hline $\mathrm{Pv}(\mathrm{Mpa})$ & 0.019 & 0.0144 & 0.029 & 0.01 \\
\hline $\mathrm{Pv}\left(\mathrm{Kg} / \mathrm{cm}^{2}\right)$ & 0.1938 & 0.1469 & 0.2958 & 0.1020 \\
\hline Bolt Spacing & 2.27 & 2.61 & 1.84 & 3.13 \\
\hline
\end{tabular}

\section{Conclusions}

The Kakaragad small hydroelectric project, a Run-of-the-river scheme, envisages the production of $12.5 \mathrm{MW}$ of electric power by constructing $1638 \mathrm{~m}$ long power tunnel with a diameter of $2.5 \mathrm{~m}$. The tunnel runs through hard and massive leucogranite body with three sets of joints. No major fault zone has been observed along the tunnel alignment. The rocks provide a good medium for tunneling.

The quality of rock mass has been assessed by RMR method of Bieniawski (1979) and it indicates that the quality of rock is very good. For support system evaluation, the Q system by Barton (1974) has been used. The $\mathrm{Q}$ values of the rocks ranges between 11.85 and 81.1, which indicates that these rocks in general are selfsupporting with minor support consisting of systematic bolting with 1.5 to $2 \mathrm{~m}$ spacing and untensioned grouting. Rock mass quality assessment and geological evaluation along tunnel alignment proves that chosen alignment is good for tunnelling.

\section{References}

[1]. Barton, N., Lien, R., and Lunde, J.; (1974), Engineering Classification of Rock Masses for the Design of Tunnel Support; Rock Mechanics, Springer-Verlag, vol.6; pp 189-236

[2]. Bieniaswksi, Z. T., (1989); Engineering Rock Mass Classification; Jhon Willey \& Sons. LTD., London; pp 30-90

[3]. Singh, B., Goel, R. K.,(1999); Rock Mass Classification- A Practical Approach in Civil Engineering; Elsvier Science Ltd., Oxford; pp 34-89

[4]. Jain, A.K., Singh, S., and Manickavasagam, R.M.(2002); Himalayan Collision Technocic; Gondwana research group, Memoir no. 7; pp 57-101 